\title{
NUMERICAL STUDY OF OIL SPILL IN THE PATOS LAGOON ESTUARY REGION
}

\author{
T. F. Leal ${ }^{\mathrm{a}}$, \\ C. B. Monteirob \\ M. C. Silva ${ }^{a}$, \\ O. O. Möller ${ }^{b}$, \\ P. H. Oleinik ${ }^{a}$, \\ and W. C. Marques \\ ${ }^{a}$ Universidade Federal do Rio Grande \\ Pós-Graduação em Engenharia Oceânica \\ Escola de Engenharia \\ Bairro Carreiros \\ CP. 474, Rio Grande, RS, Brasil \\ thalitaeinstein-fisica@hotmail.com \\ mauren_costa@hotmail.com \\ phe.h.o1@gmail.com \\ ${ }^{b}$ Universidade Federal do Rio Grande \\ Pós-Graduação em Oceanografia \\ Instituto de Oceanografia \\ Bairro Carreiros \\ CP. 474, Rio Grande, RS, Brasil \\ monteirocbm@gmail.com \\ moller.furg@gmail.com \\ ABSTRACT \\ The consumption pattern of the world population is based on petroleum \\ derivatives, which despite contributing to the improvement of the quality of \\ life, has negative aspects, mainly in the environmental scope. The number of \\ oil spills in water slide has increased significantly in recent years. \\ Considering the complexity of the marine environment, the present work \\ aims to apply a identification system of the dynamics and dispersion of oil, \\ using the numerical modeling in the region of Franceses Bridge, near to \\ Patos Lagoon-RS, Brazil. The study of hypothetical events of oil leakage in \\ the region is of fundamental importance, since the Riograndense Petroleum \\ Refinery is located inside of the Patos Lagoon estuary. A data structure of \\ atmospheric and oceanic circulation was organized and inserted in the \\ coupling between the hydrodynamic module Telemac-3D and the ECOS oil \\ model, during the period between 2010 and 2013. The coupling of these \\ models provided satisfactory results, requiring a level of computational \\ effort favorable to obtaining of results capable of giving technical and \\ scientific support to studies such as those of environmental impacts and \\ contingency plans. \\ Keywords: heat transfer enhancement; optimal geometry; eccentricities \\ Received: February 28, 2019 \\ Revised: March 20, 2019 \\ Accepted: April 14, 2019
}

\section{NOMENCLATURE}

RPR Refinaria Petróleo Riograndense

DNH Diretoria de Hidrografia e Navegação

ANA Agência Nacional de Águas

HYCOM HYbrid Coordinate Ocean Model

ECOS Easy Coupling Oil System

CHC Canadian Hydraulic Centre

DNH Diretoria de Hidrografia e Navegação

LANSD Laboratório de Análise Numérica e Sistemas Dinâmicos

ANP Agência Nacional do Petróleo

DO Observed data

DC Calculated data

ADCP Acoustic Doppler Current Profiler

\section{INTRODUCTION}

The oil pollution in oceans, estuaries and rivers is a large environmental problem, in its liquid state is an oily, flammable substance, less dense than water, it is considered a toxic substance and an accident with this substance can devastate an area and even destabilize an ecosystem. The concern with the environment regarding oil leaks has led to the development of dynamic numerical systems, in which transport and destination of oil stains are simulated. Although more than 50 models have been developed in the last decade ( $\mathrm{Li}, 2017)$, only a few are used extensively these days. These models help to obtain oil spill responses during and after accidents, assessing the environmental impact for the creation of a contingency plan and even planning.

Coastal access corridors are areas at risk of pollution from oil spills, for example, due to vessel traffic and handling of fuels, necessary for economic development in these areas. The port area of Rio Grande is an example of these areas. It centralizes several petrochemical activities, such as the RPR (Refinaria Petróleo Riograndense) localized in limits of the Patos Lagoon estuary. Thus, oil spills in the region could affect both coastal activities (e.g., fishing, tourism and leisure) and the balance of the local ecosystem, which shelters environmental features vulnerable to contact with oil, such as the mangroves that surround the coastline of Patos Lagoon. 
RPR's raw material, crude oil, is received through ships at the nearby oil-jetty close to the company. From oil tankers docked at the pier, the oil is conducted to the refinery by means of 10 " and 16 " oil ducts, with length of approximately $4 \mathrm{~km}$. These oil ducts receive oil at the oil tanker, pass under the Franceses Bridge and discharge into the RPR.

In this context, given the potential risks of oil spills in the Franceses Bridge region, located in the bottleneck that links the Patos Lagoon estuary to Mangueira Bay in Southern Brazil, this work has, as its contribution, the application of a deterministic model, capable of modeling hypothetical scenarios of crude oil leakage in the region.

\section{Location and Characteristics of the Study}

The study region is localized in the estuarine region of Patos Lagoon, Fig. 1, specifically in the vicinity of the Franceses Bridge, between $32^{\circ} 3^{\prime}$ $31^{\prime \prime} \mathrm{S}$ and $52^{\circ} 5,17^{\prime \prime} \mathrm{W}$, in the strait that connects Mangueira Bay to the middle Patos Lagoon estuary. The Patos Lagoon is located in the southern region of Brazil, between $30^{\circ}-32^{\circ} \mathrm{S}$ e $50^{\circ}-52^{\circ} \mathrm{W}$, being connected to the South Atlantic Ocean through an entrance channel of $20 \mathrm{~km}$ length and $1 \mathrm{~km}$ width (Möller et al., 2005).

Möller (1996) found that the Patos Lagoon dynamics depends essentially on Wind and freshwater discharge. The wind acting locally on the lagoon's body produces a configuration in the circulation pattern (set-up/set-down) during periods of Northeast-Southwest winds, while the longerperiod oscillations generated in the region coastal áreas by remote action of the winds are attenuated as they propagate into the lagoon (Möller et al., 2002). The combination of local and remote wind action is the main mechanism that controls the introduction of salt into the estuarine region (Möller et al., 2001).

The largest rivers (Guaíba, Camaquã and São Gonçalo) in the south of Brazil discharge their waters in this lagoon. The main contributing rivers are at the north of the lagoon and have a discharge pattern typical of temperate regions influenced by climatic processes (Marques et al., 2009).

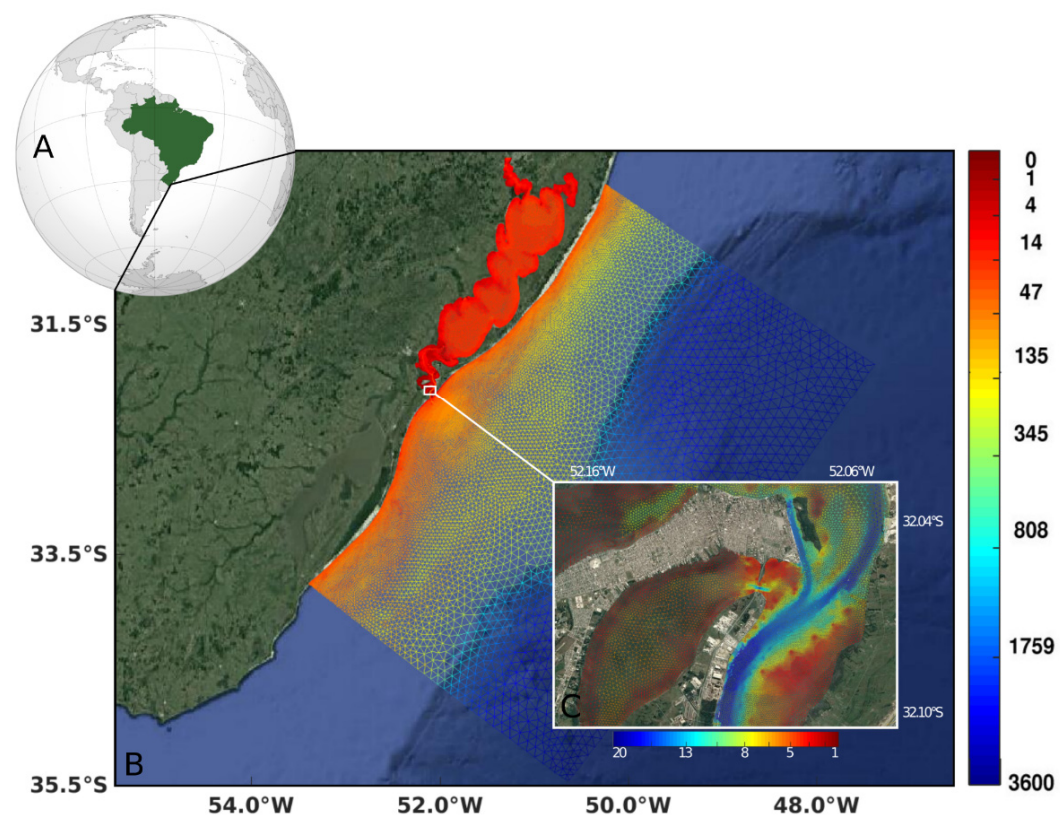

Figure 1. Study area location (A), bathymetric in meters (B), superimposed by Google maps, lansdsat/Copernicus.

The highlighted area is the strait that connects Mangueira Bay to the middle Patos Lagoon estuary (C), exact location of the study region.

\section{METHODOLOGY}

The methodology of this work consists in the use of numerical modeling and direct analysis of the obtained results. The numerical modeling system used is Telemac, through the hydrodynamic module Telemac-3D developed within the consortium open Telemac-MASCARET. To describe the behavior of the oil in the study region, the ECOS model developed at the Universidade
Federal do Rio Grande-FURG, at the Laboratório de Analise Numérica de Sistemas DinâmicosLANSD, that has already been used in similar work on the brazilian South Continental Shelf (Marques et al., 2017).

\section{Computational Mesh}

The computational mesh was generated by the software Blue Kenue developed by $\mathrm{CHC}$. The 
triangles present variable values in the domain: $11000 \mathrm{~m}$ in the oceanic zone, $300 \mathrm{~m}$ in Patos Lagoon and $100 \mathrm{~m}$ in the mouth of Patos Lagoon and $30 \mathrm{~m}$ in the oil spill release region, thereby the mesh has a total of 93050 nodes. The bathymetry data of the study region were extracted and digitized from nautical charts provided by Diretoria de Hidrografia e Navegação DNH. The nautical charts used were 2140 (Patos Lagoon), 2350 (Pinhal ao Rio Grande) and 2112 (Rio Grande to Chuí stream).

\section{Hydrodynamic Model Telemac-3D}

The Telemac-3D solves the Navier-Stokes equations considering local free surface variation and neglecting the density variation in the mass conservation equation and considering the Boussinesq approximation to solve the momentum equations, for a detailed mathematical description of the model see Hervouet (2007). The oceanographic forcing for the hydrodynamic model is provided by the HYCOM. The Grenoble Tide Model and the freshwater discharge are provided by the ANA. The atmospheric conditions (wind, pressure and air temperature) come from the ERAInterim Reanalysis data sets.

\section{Ecos Model}

The ECOS model was developed in LANSD, and has register in Instituto Nacional da Propriedade Industrial- INPI number 51201300013. The ECOS is a numerical model that describes the behavior of the oil particles as discrete, using the Lagrangean approximation to evaluate the properties over time. The simulation was performed using 40000 particles and the oil displacement is evaluated considering an inhomogeneous oil smudge. For a detailed mathematical description of the concepts used to support the development of the ECOS model, see Marques et al. (2017).

\section{Initial and Boundary Conditions}

The initial and boundary conditions are necessary to solve the hydrodynamic equations of Telemac-3D. The data were extracted from different sources for the domain of the model, then interpolated and prescribed, for each point of the finite element mesh. The model was executed for a 2 years (2010 and 2011) simulation, and was initialized from rest.

The ECOS model considers the oil spill punctual and assumes a circular geometry when spilled in the water. The initial area is calculated according to Fay (1969) and the initial spreading phase is fast. The oil information used in the ECOS model was obtained in the technical report from
ANP. The characteristics of the oil are presented in the Tab. 1.

Table 1. Characteristics of the oil used in the numerical simulations.

\begin{tabular}{|c|c|}
\hline Oil Type & $\begin{array}{c}\text { Marine Fuel 380 } \\
\text { (MF-380) }\end{array}$ \\
\hline Oil Initial Volume & $13 \mathrm{~m}^{3}$ \\
\hline Sea Water Density & $1025 \mathrm{~kg} / \mathrm{m}^{3}$ \\
\hline Oil Density & $980 \mathrm{~kg} / \mathrm{m}^{3}$ \\
\hline${ }^{\circ}$ API & 28 \\
\hline Saltwater & $0.000893 \mathrm{~m}^{2} \mathrm{~s}$ \\
\hline Particle Volume & $0.05 \mathrm{~m}^{3}$ \\
\hline
\end{tabular}

The Telemac-3D has three types of contour conditions: river discharge, ocean and solid contours. The contours of fluvial discharge come from the tributaries of the Patos Lagoon, Guaíba River, Camaquã River and the São Gonçalo channel. The ocean contours account for astronomical tide data, current velocities, salinity, and seawater temperature.

\section{Validation Hydrodynamic}

The Telemac-3D model was validated for the investigation of hydrodynamic processes as performed in the studies of Marques et al. (2017). In the current study, a similar parameterization was used to perform the validation of three-dimensional numerical simulations.

The hydrodynamic simulation used to verify the quality of the results was conducted for the period of 2 years, between the period 01/01/2010 and $12 / 31 / 2011$. This information was used to validate the results of the model, through the comparison with the measures of time series observed in the field. In this case, the hydrodynamic result of the simulation was compared with the observations of current velocities measured the access channel to Patos Lagoon, at Praticagem Station, from 06/01/2011 to $30 / 01 / 2011$. The current data were obtained with a ADCP positioned in the navigation channel (Fig. 2) at a depth of $12 \mathrm{~m}$. To improve the comparison between time series, a Lanczos cosine filter was used to remove the high frequency oscillations (periods less than $12 \mathrm{~h}$ ) of the time series.

The Fig. 3 presents the comparison between the time series with observed data (D.O) and the calculated data (D.C), obtained through numerical simulation. The performance of the simulations was quantified by the same method used by Marques et al. (2017).

The comparison between the time series of calculated current velocity indicates that the model can reproduce the velocity signal trends in the Patos Lagoon channel. The main differences, as shown in 
Fig. 3, appear in the period from 12 to 14 in January and also the period in January, 17 to 22, where the calculated data are underestimated with respect to the observed data. According to Marques et al. (2017) the underestimation of the calculated time series may be related to the use of a constant wind spacial influence coefficient, absence of waves generated by winds in the hydrodynamics or due to the use of data sets of low space-temporal resolution.

The evaluations of the comparisons presented use performance indicators such as those used in Marques et al. (2017) and Oleinik et al. (2017). The RMSE associated with the in current velocity is $0.21 \mathrm{~m} / \mathrm{s}$ and the MAE for the surface component is $0.17 \mathrm{~m} / \mathrm{s}$. The verification indicates that despite the limitations in the data used to force and verify the numerical model, the time series of current velocity represents the trends of the signals measured in the estuarine channel of the Patos Lagoon, as well as the results obtained by Marques et al. (2017).

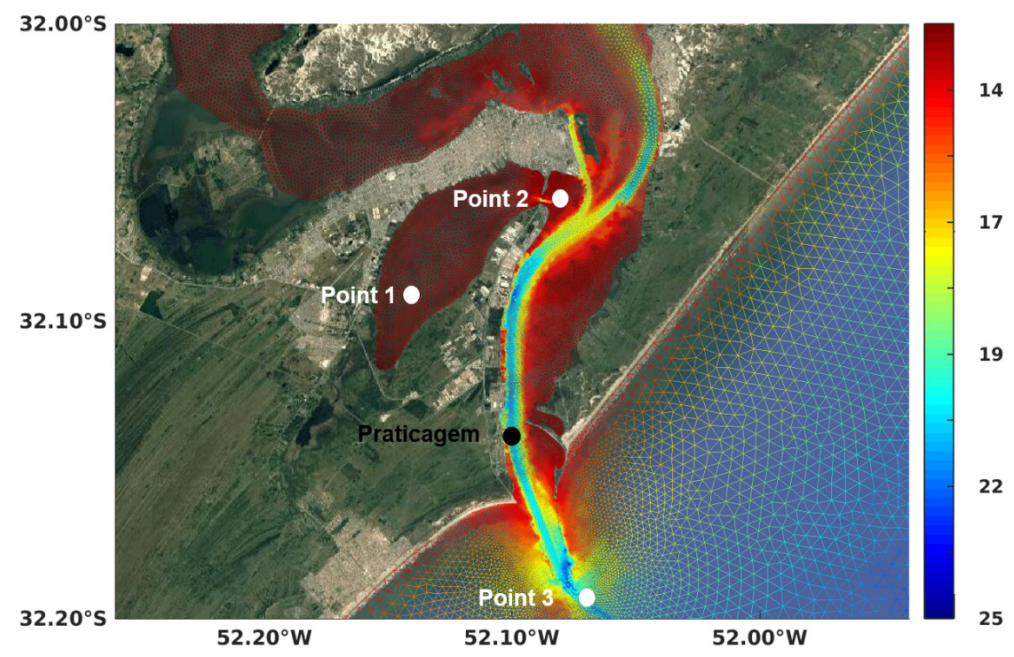

Figure 2. Equipment Position: The black dot indicates the ADCP position in the Patos Lagoon access channel, at the coordinates $32^{\circ} 8^{\prime} 12^{\prime \prime} \mathrm{S}$ and $52^{\circ} 6^{\prime} 9$ " $\mathrm{W}$. White points 1,2 and 3 indicate where the time series of elevation were extracted.

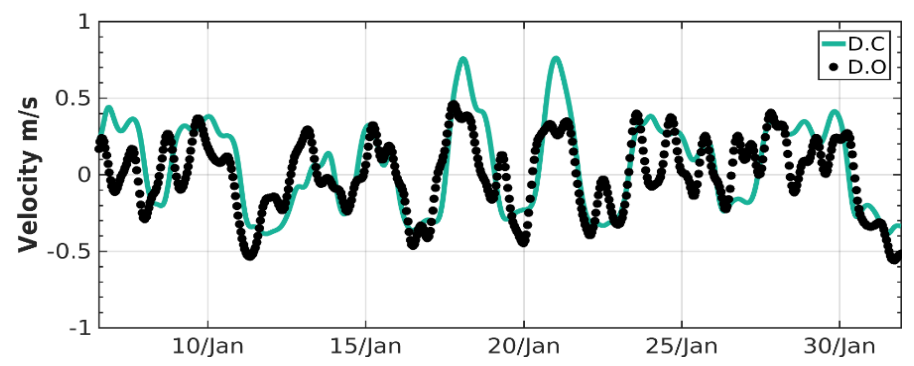

Figure 3. In black, the observed data (D.O) are represented, and in green, the data calculated by the model (D.C) are presented.

\section{RESULTS}

To the understanding the region dynamics, a time serie of elevation calculated by the model was elaborated in order to indicate the periods of flood and ebb. With the conditions of flood and ebb it was possible to identify scenarios for hypothetical oil leaks.

The behavior analysis and displacement of the oil plume and the other properties of weathering are indicated. According Möller (1996) the set-up and set-down mechanism, which combines local and nonlocal wind action, as well as the fluvial discharge of the main tributaries (Guaíba, Camaquã and São Gonçalo) are the most important factors that force the water exchange between Patos Lagoon and adjacent continental shelf, causing periods of flood, marked by the entrance of saline water fronts coming from the mouth of the Patos Lagoon access channel, and periods of ebb, which represent the exiting of the waters of the estuary.

The time series in the Fig. 4 were extracted from three different points. Point 1 (green line) is localized inside Mangueira Bay, Point 2 (blue line) is located in the estuary access channel, near the city of Rio Grande and Point 3 (red line) is situated in the exit of the jetties. These points are shown in Fig. 2. The time series extracted in Point 1 and 2 show a strong relationship between the elevation in the bay and the elevation in the estuary, as already observed 
in Monteiro et al. (2006).

Analyzing the initial period of each month (Fig. 4), the months January, February, March, April, May, July, September, October and December show ebb conditions, where elevation of points 1 and 2 (green and blue line) are higher than point 3 (red line), unlike the months of June, August and November, which present a flood condition, where the elevation of point 3 (red line) is higher than point 1 and 2 . This oscillation in is associated to winds and passage of frontal systems (Möller et al., 2001).

In this sense, from the results obtained in the elevation time series, a period under ebb condition was selected, highlighted in Fig. 4, to simulate a hypothetical oil leak in the region of Franceses Bridge.

In this sense, from the results obtained in the elevation time series, a period under ebb condition was selected, highlighted in Fig. 4, to simulate a hypothetical oil leak in the region of Franceses Bridge.

\section{Displacement of Oil Particles}

For the oil leak scenario, a volume of $13 \mathrm{~m}^{3}$ under the Franceses Bridge (on the water surface), where the oil ducts that transports the oil from the oil tanker until the RPR.

The oil plume was tracked until its arrival in the coastal limits, during $24 \mathrm{~h}$, after the accident. Due to the lack of data to validate this model, the results are analyzed with a qualitative approach to evaluate the results.

The oil volume is dumped instantly beginning on May 24, 2010 at $12 \mathrm{~h}$. The oil particles are represented in black and the current variation intensity can be observed in the Fig. 5. After $7 \mathrm{~h}$ the oil plume reaches the interior of the Mangueira Bay and the coastal limits of the Rio Grande's industrial region, driven by the moderate northwest and northeast winds of approximately 6 and $8 \mathrm{~m} / \mathrm{s}$ (Fig. 6).

\section{Oil Wethering}

The simulation of the trajectory of the oil particles during the leak simulation is not enough to explain the whole process that controls the displacement of the oil particles, so an analysis of the weathering was performed. The oil leakage is not homogeneous in all directions, but, as pointed in Marques et al. (2017), the oil weathering was studied considering the homogeneous properties between the particles, since the oil leak occurs on a small scale.

The Fig. 7 show the evaporation and emulsification temporal behavior. All time series were calculated using the ECOS model coupled to Telemac-3D. The maximum evaporation is $0.42 \%$ after $5 \mathrm{~h}$. Fingas (2012) showed that the equation used to evaluate evaporation generally overestimates the evaporation of the oil. Emulsification is highly dependent on hydrodynamic conditions of water and wind. The emulsion has a maximum water content of about $60 \%$.

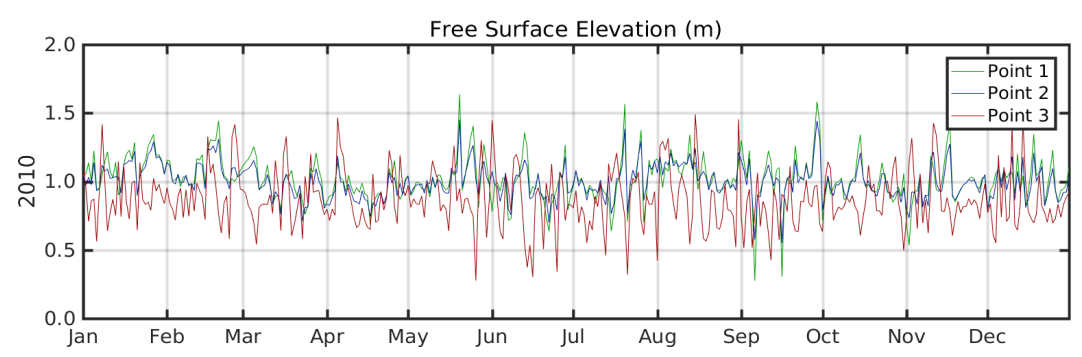

Figure 4. Elevation Time Series calculated by Telemac-3D.
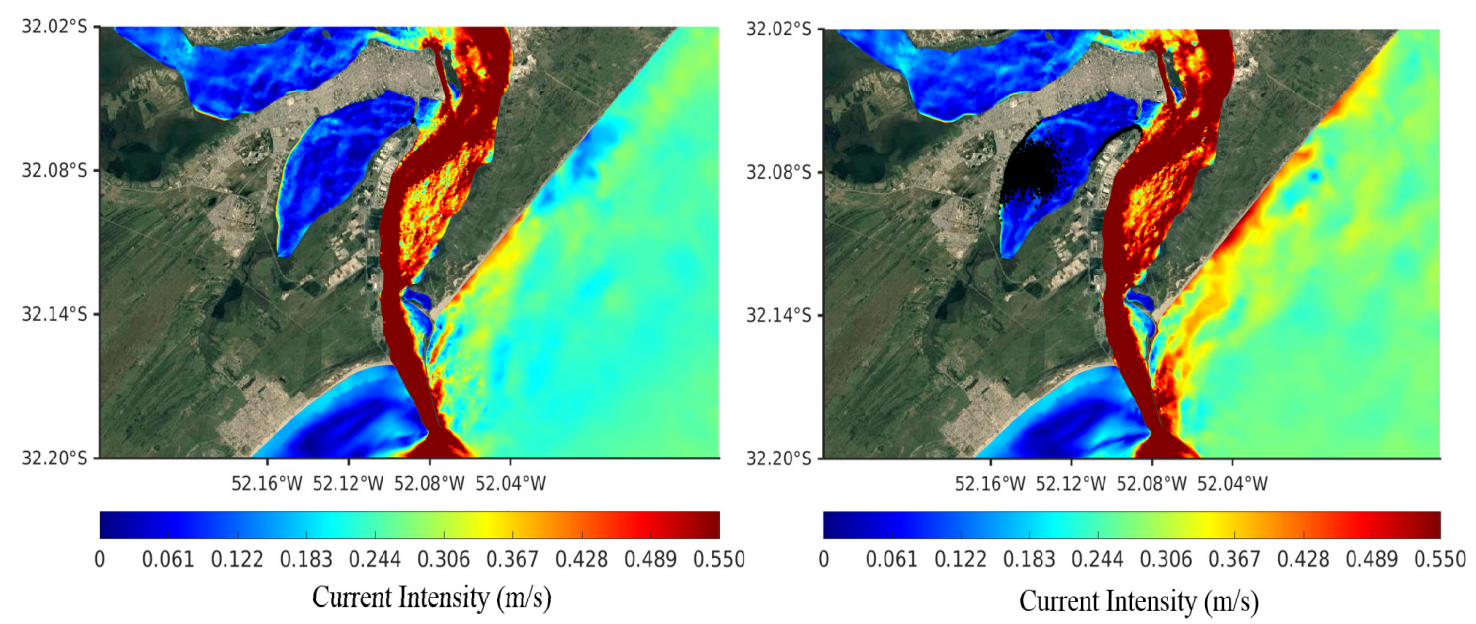

Figure 5. Oil particles displacement after 1 hour and oil particles displacement after 7 hours. 

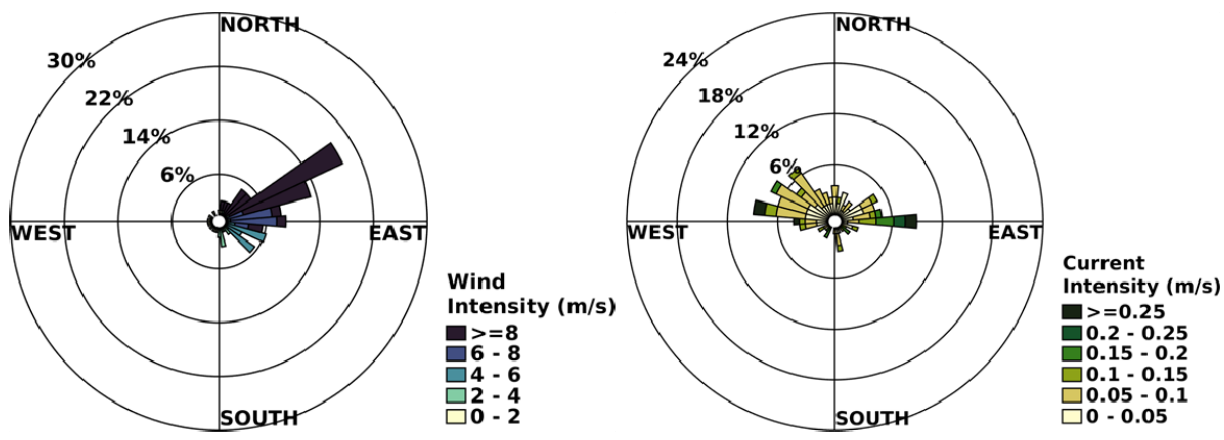

Figure 6 . Wind intensity histogram and current intensity histogram.

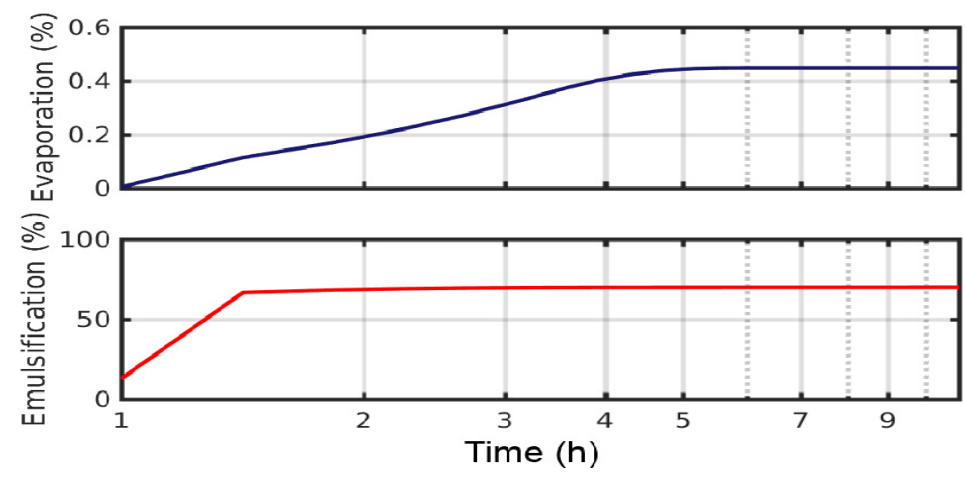

Figure 7. Oil evaporation and emulsification.

\section{CONCLUSIONS}

The behavior and destination of oil spill on March 1, 2010, in the Franceses Bridge region, was numerically investigated using an ECOS model coupled to Telemac-3D. The elaboration of a time series of elevation was presented with the purpose of presenting the conditions of ebb and flood in the region. From these conditions an ebb event, typical of the region, was selected to analyze the displacement of the oil plume influenced by the winds and currents velocity.

Analysis of the oil stain behavior and the weathering properties during the simulated period were performed.

The main conclusions of this work are:

- The results of the oil displacement particles indicate that after $6 \mathrm{~h}$ the oil spill reaches the interior of the Mangueira Bay and the coastal limits of the Rio Grande industrial region, driven by winds and currents velocity representing the main physical factors that control the behavior and final destination of the oil.

- The oilweathering properties indicate $0.45 \%$ evaporation, the formation of an emulsion with a water content of $60 \%$.

- It will be necessary to simulate other critical oil leakage scenarios, to analyze which regions will be affected under other ebb and flood conditions.

\section{ACKNOWLEDGMENT}

The authors gratful for Coordenação de
Aperfeiçoamento de Pessoal de Nível Superior (CAPES) for the grant of scholarships, the Conselho Nacional de Desenvolvimento Científico e Tecnológico (CNPq) by contract 304227 / 2016-1, to the Fundação de Amparo à Pesquisa do Estado do Rio Grande do Sul (FAPERGS) by contract 17/ 2551-0001159-7 and the Centro Nacional de Supercomputação (CESUP), Universidade Federal of Rio Grande do Sul (UFRGS), which helped to develop this work. Thank you, ECMWF for the oceanographic and meteorological data boundary conditions of the model, to the Open TELEMACMASCARET consortium for the TELEMAC system free of charge and to the Laboratório Nacional de Computação Científica (LNCC) for the provision of use of the Santos Dumont Supercomputer.

\section{REFERENCES}

Brekke, C., and Solberg, A. H., 2005, Oil Spill Detection by Satellite Remote Sensing, Remote Sensing of Environment, Vol. 95, No. 1, pp. 1-13.

Calliari, L. J., Winterwerp, J., Fernandes, E. H. L., Cuchiara, D., Vinzon, S. B., Sperle, M., and Holland, T., 2009, Fine Grain Sediment Transport and Deposition in the Patos Lagoon-Cassino Beach Sedimentary System, Continental Shelf Research, Vol. 29, pp. 515-529.

Fay, J. A., 1969, The Spread of Oil Slicks on a Calm Sea, Springer.

Fingas, M., 2012, The Basics of Oil Spill Cleanup, CRC Press.

Hervouet, J. M., 2007, Hydrodynamics Of Free 
Surface Flows. Modelling with The Finite Element Method, John Wiley \& Sons.

Janeiro, J., Fernandes, E. H. L., Martins, F., and Fernandes, R., 2008, Wind and Freshwater Influence Over Hydrocarbon Dispersal on Patos Lagoon, Brazil, Marine Pollution Bulletin, Vol. 56, No. 4, pp. 650-665.

Jones, B., 1999, The Use of Numerical Weather Prediction Model Output in Spill Modelling, Spill Science \& Technology Bulletin, Vol. 5, No. 2, pp. 153-159.

Li, S., 2017, Evaluation of New Weathering Algorithms, Master Thesis, University Halifax, NS.

Marques, W. C., and Möller, O., 2009, Variabilidade Temporal em Longo Período da Descarga Fluvial e Níveis de Água da Lagoa dos Patos, Revista Brasileira de Recursos, pp. 155-163. (in Portuguese)

Marques, W. C., Stringari, C. E., Kirinus, E. P., Möller Jr., O. O., and Toldo Jr., E. E., 2017, Numerical Modeling of the Tramandaí Beach Oil Spill, Brazil-Case Study for January 2012 Event, Applied Ocean Research, Vol. 65, pp.178-191.

Möller, O. O., Castaing, P., Salomon, J. C., and Lazure, P., 2001, The Influence of Local and NonLocal Forcing Effects on the Subtidal Circulation of Patos Lagoon, Estuaries, Vol. 24, pp. 297-311.

Monteiro, I. O., Pearsom, M., Möller, O. O., and Fernandes, E. H. L., 2006, Hidrodinâmica do Saco da Mangueira: Mecanismos que Controlam as Trocas com o Estuário da Lagoa dos Patos, Atlântica, Vol. 27, No. 2, pp. 8-101. (in Portuguese)

Möller, O. O., 1996, Hydrodynamique de la Lagune dos Patos (30os, Brésil): Mesures et Modélisation, Doctoral Thesis, Université Bordeaux 1 Sciences et Technologies, FR.

Oleinik, P. H., Marques, W. C., and Kirinus, E. P., 2017, Estimate of the Wave Climate on the Most Energetic Locations of the South-Southeastern Brazilian Shelf, Defect and Diffusion Forum, Vol. 370, pp. 130-140. 